\title{
Rancang Bangun Alat Pemotong Ikan Patin Otomatis untuk Bahan Baku Ikan Salai
}

\author{
Edilla $^{1^{*}}$, Rudi Fesri ${ }^{1}$, Made Rahmawaty ${ }^{1}$, Hendriko $^{1}$ \\ *Politeknik Caltex Riau \\ Mechatronic Engineering Study Program \\ Umbansari Street, Rumbai 28265, Indonesia \\ edilla@pcr.ac.id, rudifesriwandira@alumni.pcr.ac.id, made@pcr.ac.id, hendriko@pcr.ac.id
}

\begin{abstract}
Abstrak
Ikan patin (Pangasius sp) merupakan salah satu jenis ikan yang banyak dijadikan sebagai bahan baku untuk olahan ikan salai. Ikan Salai merupakan salah satu kuliner lokal yang diolah dengan proses pemotongan/pembelahan serta pengeringan dan penyalaian (pengasapan) yang dilakukan kurang lebih 1-2 hari dan merupakan salah satu kuliner yang sangat familiar di Indonesia, khususnya Provinsi Riau. Namun, dalam pembuatan olahan ikan salai ini proses pemotongan/pembelahan ikan masih dilakukan secara manual. Hal ini dapat diatasi dengan alat feeder dan pemotong ikan patin otomatis. Cara kerja dari alat ini yaitu ikan yang masih segar akan diletakkan secara manual pada belt konveyor lalu ikan akan berjalan menuju proses pemotongan ikan menggunakan mata pisau bulat yang berputar dan akan memotong ikan sesuai dengan kedalaman yang telah disesuaikan untuk bahan baku olahan ikan salai patin. Dari pengambilan data yang dilakukan dengan menggunakan 20 ekor ikan dengan berat berkisar 150 - 365 gram dan panjang ikan berkisar $23-35 \mathrm{~cm}$, waktu rata-rata dari pengerjaan 20 ekor ikan tersebut adalah 2,27 sekon. Untuk menentukan kapasitas alat, dilakukan proses pemotongan 5 ekor ikan secara kontinu dan waktu yang dihasilkan adalah 6,02 sekon, jadi dalam 1 menit alat ini mampu mengolah ikan patin sebanyak kurang lebih 48-49 ekor ikan per menit.
\end{abstract}

Kata kunci: Ikan patin (Pangasius sp), Ikan salai, Feeder, Pemotongan, Belt konveyor.

\begin{abstract}
Catfish (Pangasius sp) is a type of fish that is widely used as raw material for processed smoked fish. Salai fish is one of the local culinary delights that are processed by cutting / splitting as well as drying and curing (smoking) which takes approximately 1-2 days and is one of the most familiar culinary delights in Indonesia, especially in Riau Province. However, in making this processed smoked fish, the process of cutting / splitting the fish is still done manually. This can be overcome by means of automatic feeder and catfish cutter. The way this tool works is that fresh fish will be put manually on the conveyor belt then the fish will go to the fish cutting process using a rotating circular blade and will cut the fish according to the depth has been adjusted for the raw material for processed catfish smoked fish. From data collection using 20 fish with a weight ranging from 150 to 365 grams and a length of fish ranging from $23-35 \mathrm{~cm}$, the average working time of the 20 fish is 2,27 seconds. To determine the capacity of the tool, a continuous cutting process of 5 fish was carried out and the resulting time was 6,02 seconds, so in 1 minute this tool was able to process catfish as much as 48-49 fish per minute.
\end{abstract}

Keywords: Catfish (Pangasius sp), Smoked Fish, Feeder, Cutting, Conveyor Belt. 


\section{Pendahuluan}

Ikan banyak sekali jenisnya dan salah satunya adalah Patin. Ikan patin (Pangasisus $s p$ ) merupakan jenis ikan konsumsi air tawar asli Indonesia yang tersebar di sebagian wilayah Sumatera khususnya Provinsi Riau. Daging ikan patin memiliki kandungan kalori dan protein yang cukup tinggi, rasa dagingnya khas, enak, lezat dan gurih sehingga digemari oleh masyarakat. Ikan patin dinilai lebih aman untuk kesehatan karena kadar kolesterolnya rendah dibandingkan dengan daging hewan ternak [1]. Oleh karena itu, ikan patin banyak sekali dibudidayakan oleh masyarakat di Provinsi Riau, khususnya di Kabupaten Kampar. Gambar 1 berikut merupakan gambar dari bentuk ikan patin.

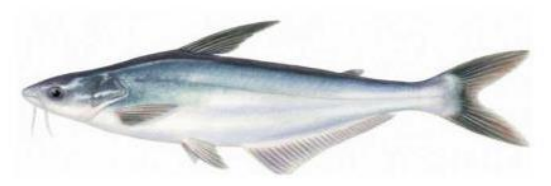

Gambar 1: Ikan patin

Sejak tahun 1998, budidaya ikan patin sudah marak dijumpai di Kabupaten Kampar, dan mulai saat itu produksi ikan patin di Kabupaten Kampar semakin besar. Untuk mengatasi kelimpahan panen tersebut maka beberapa pembudidaya dengan kreatif mencoba mengolah ikan patin segar menjadi produk olahan ikan salai atau ikan asap [1]. Gambar 2 berikut merupakan gambar dari proses pengasapan ikan salai.

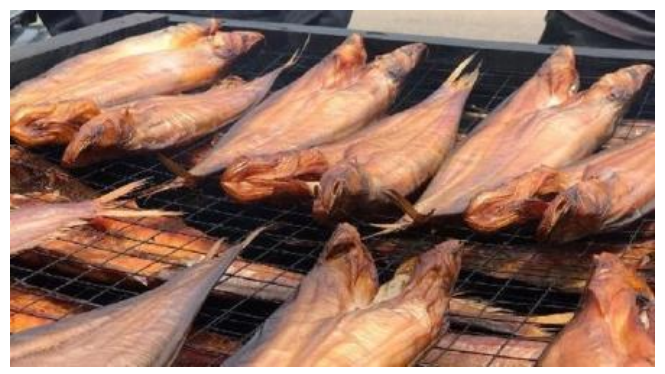

Gambar 2: Proses pengasapan ikan salai

Mengenai proses pengolahan ikan patin segar menjadi ikan salai patin tidaklah terlalu rumit. Proses pengolahan dimulai dari ikan patin segar yang dipanen dari kolam warga setiap paginya, kemudian dibersihkan oleh beberapa ibu-ibu yang mana dalam satu tempat pengolahan ikan salai rata-rata bisa mempekerjakan minimal tujuh orang. Dengan jumlah pekerja sebanyak itu, satu orang pengusaha bisa mengolah ikan patin segar sampai 1 ton per hari. Ikan patin segar 1 ton tersebut biasanya akan menghasilkan ikan salai patin mencapai 300 kilogram [2]. Berdasarkan literatur, terdapat beberapa penelitian terdahulu mengenai alat pemotong ikan otomatis antara lain: M. Lukman Hakim yang melakukan penelitian kecepatan putar pisau potong. Dalam penelitiannya ini, ikan yang digunakan adalah ikan sarden, dan kelebihan alat ini yaitu kecepatan pisau bulat pemotongnya sudah dikontrol dengan PID (Proportional Integral Derivative) selain itu juga pada konveyor terdapat bagian celah untuk mempermudah proses pemotongan bagian kepala dan ekor ikan sarden dan untuk kekurangannya sendiri, proses filleting atau pemotongan bagian perut masih dilakukan secara manual [3]. Selanjutnya adalah Filleting Machine CT 2630 Salmon Filleting” yang diproduksi oleh Marel Industries. Kelebihan alat ini yaitu terdapat dua metode pemotongan yaitu menggunakan Splitting band (Pisau pita) dan Circular Knife (Pisau bulat) dan dapat memproses hingga 25 ekor ikan per menit tergantung panjang ikan yang digunakan. Namun kekurangan dari alah ini adalah ukuran alat ini sangat besar dan ikan yang dapat diproses berukuran 2-7 Kg per ekor [4]. Dan yang terakhir adalah Fengxiang Food Machinery Model: FGB-168 Small Fish Filleting Machine. Dimana alat ini menggunakan isau bulat untuk memotong ikan dan selain itu kelebihannya dalah menggunakan sumber 3 phasa $380 \mathrm{~V} / 50 \mathrm{~Hz}$ serta konstruksi baja. Namun, kekurangan alat ini hanya cocok untuk memotong ikan kecil yang tingginya kurang lebih $40 \mathrm{~mm}$ [5]. Berdasarkan ketiga penelitian terdahulu tersebut, penelitian akan merancang dan membuat Alat feeder dan pemotong ikan mengacu kepada Fengxiang Food Machinery Model: FGB168 Small Fish Filleting Machine, sedangkan untuk metode pemotongannya sendiri akan menggunakan pisau bulat yang akan digerakkan menggunakan motor induksi 1 phase, dan untuk proses feeder masih dilakukan secara manual menuju belt konveyor yang akan menarik ikan menuju proses pemotongan menggunakan pisau pemotong bulat tersebut. Tujuan dari penelitian ini adalah merancang dan membuat alat feeder dan pemotong ikan otomatis yang dapat membantu proses pemotongan ikan agar didapat bahan baku pembuatan ikan salai yang lebih higienis.

\section{Metodologi}

Untuk menjawab permasalahan tersebut maka dilakukan kajian dan perancangan sistem alat yang akan dibuat. Adapub blok diagram dari penelitian ini dapat dilihat pada gambar 3. Alat pada penelitian ini menggunakan kontrol sekuansial, motor Ac 1 fasa sebagai penggerak pisau, motor DC sebagai penggerak konveyor dan pompa air DC untuk membersihkan ikan.

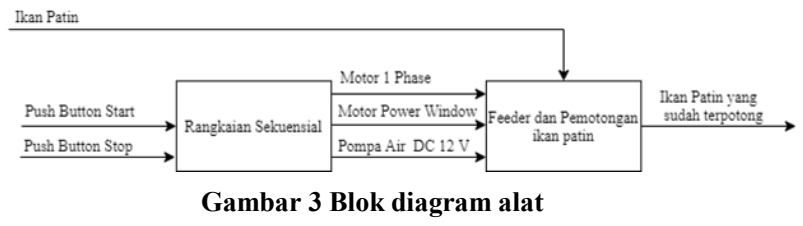

Untuk mengetahui hasil perancangan Alat Feeder dan Pemotong pada Mesin Pemotong Ikan Patin Otomatis untuk Proses Pembuatan Ikan Salai ini sesuai dengan yang diharapkan atau tidak maka diambil data-data 
untuk membuktikannya. Dari Alat Feeder dan Pemotong pada Mesin Pemotong Ikan Patin Otomatis untuk Proses Pembuatan Ikan Salai yang telah dibuat dilakukan pengujian-pengujian untuk mengetahui kinerja dari alat tersebut. Berikut adalah beberapa data yang perlu diambil dari Alat Feeder dan Pemotong pada Mesin Pemotong Ikan Patin Otomatis untuk Proses Pembuatan Ikan Salai:

\section{Pengujian Keberhasilan Konveyor Mengantar Ikan Menuju Proses Pemotongan}

Setelah ikan patin di feeder (diumpan) secara manual ke belt konveyor, maka selanjutnya belt konveyor akan mengantarkan ikan menuju proses pemotongan menggunakan mata pisau berdiameter 10 inch. Berhasil atau tidaknya belt konveyor mengapit dan mengantarkan ikan patin menuju proses pemotongan menjadi salah satu faktor keberhasilan alat ini. Data yang diambil dalam pengujian ini adalah hasil pengamatan dari pengujian berat ikan patin terhadap tingkat keberhasilan belt konveyor, yaitu berhasil atau tidaknya belt konveyor mengapit dan mengantar ikan patin menuju proses pemotongan.

\section{Pengujian Keberhasilan Proses Pemotongan Ikan Patin}

Alat feeder dan pemotong ikan pada mesin pemotong ikan patin otomatis untuk proses pembuatan ikan salai ini menggunakan mata pisau bulat berdiameter 7 inch yang mana pada saat pengujian dilakukan redesain menjadi mata pisau berdiameter 10 inch dengan jumlah teeth sebanyak 120 yang digerakkan oleh motor 1 phase. Penggunaan mata pisau dengan teeth yang banyak ini bertujuan agar hasil pemotongan ikan patin lebih bagus. Data yang diambil dalam pengujian ini adalah pengujian berat ikan patin terhadap tingkat keberhasilan dari proses pemotongan ikan patin dalam proses pemotongan ikan patin tersebut.

\section{Pengujian Durasi Keseluruhan Proses Untuk 20 Ekor Ikan Patin Dengan Berat Yang Bervariasi}

Durasi waktu yang dibutuhkan untuk memotong ikan patin berbeda-beda. Hal ini tergantung dari ukuran ikan patin yang digunakan untuk proses feeder dan pemotongan. Proses diawali dengan proses feeder (pengumpan) ikan secara manual terlebih dahulu, dengan harapan ikan akan tepat posisinya terapit oleh belt konveyor. Kemudian ikan yang sudah terapit oleh belt konveyor akan diantar memasuki tahap pemotongan, setelah tahap pemotongan selesai, ikan patin yang telah terpotong akan masuk ke tahap pembersihan dan pemipih. Data yang diambil adalah durasi yang dibutuhkan untuk melakukan keseluruhan sistem yaitu, dari proses feeder (pengumpanan) ikan sampai dengan ikan patin terpotong. Dalam proses pengambilan data juga ditetapkan variabel bebas yaitu jenis ikan patin yang digunakan berkisar 152 gram sampai dengan 603 gram. Proses pengambilan data dilakukan dengan melakukan pengukuran berat dan panjang ikan patin terlebih dahulu, seperti yang terlihat pada Gambar 4. Kemudian ikan patin yang sudah ditimbang dan diukur panjangnya akan dimasukkan atau diumpankan (feeder) ke dalam lintasan belt konveyor untuk diantarkan menuju proses pemotongan menggunakan mata pisau berdiameter 10 inch. Gambar 5 berikut adalah gambar proses feeder (pengumpanan) ikan patin secara manual.
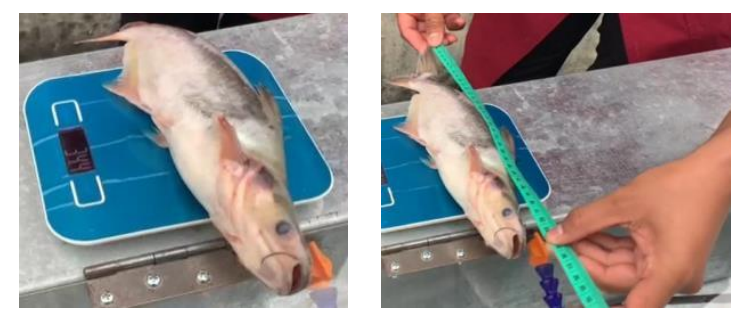

Gambar 4 Penimbangan dan pengukuran panjang ikan

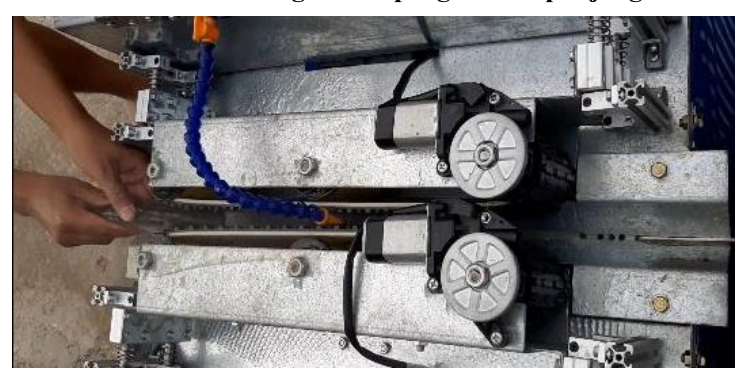

Gambar 5 Proses feeder ikan

\section{Pengujian Durasi Keseluruhan Proses Untuk Ikan Patin Berukuran 150-250g}

Data yang diambil adalah durasi yang dibutuhkan untuk melakukan keseluruhan sistem yaitu, dari proses feeder (pengumpanan) ikan sampai dengan ikan patin terpotong. Dalam proses pengambilan data juga ditetapkan variabel bebas yaitu jenis ikan patin yang digunakan berkisar 152 gram sampai dengan 256 gram, ukuran tersebut sudah disesuaikan dengan hasil riset mengenai berapa berat ideal ikan patin yang digunakan sebagai bahan baku untuk olahan ikan salai patin dipasaran.

\section{Pengujian Tingkat Fleksibilitas Konveyor Pada} Alat

Alat Feeder dan Pemotong pada Mesin Pemotong Ikan Patin Otomatis untuk Proses Pembuatan Ikan Salai ini didesain dengan sistem konveyor yang fleksibel agar dapat menyesuaikan ukuran ikan yang digunakan dalam proses pengolahannya. Dengan adanya variasi ini mengakibatkan durasi waktu yang dibutuhkan untuk keseluruhan proses dalam mengolah ikan patin pun berbeda-beda. Hal ini tergantung dari ukuran ikan patin yang digunakan untuk proses feeder dan pemotongan. Proses diawali dengan proses feeder (pengumpan) ikan secara manual terlebih dahulu, dengan harapan ikan akan tepat posisinya terapit oleh belt konveyor. Kemudian ikan yang sudah terapit oleh belt konveyor yang sudah didesain agar menjadi fleksibel dan akan diantar memasuki tahap pemotongan, setelah tahap pemotongan selesai, ikan patin yang telah terpotong akan masuk ke tahap pembersihan dan pemipih. 
Data yang diambil adalah tingkat keberhasilan fleksibilitas konveyor dan juga durasi yang dibutuhkan untuk melakukan keseluruhan sistem yaitu, dari proses feeder (pengumpanan) ikan sampai dengan ikan patin terpotong. Dalam proses pengambilan data juga ditetapkan variabel bebas yaitu jenis ikan patin yang digunakan berkisar 265 gram sampai dengan 603 gram. Gambar 6 berikut merupakan perbandingan kondisi sistem pegas konveyor sebelum dan sesudah ikan terapit.

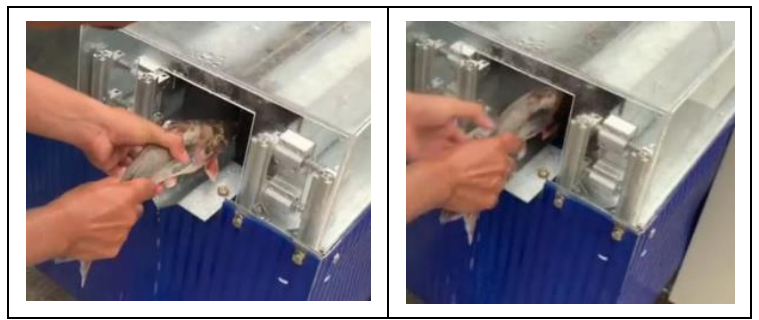

Gambar 6: Kondisi pegas sebelum dan sesudah ikan dimasukkan

Data hasil pengujian yang terkumpul akan dianalisis. Untuk data hasil pengujian tingkat fleksibilitas konveyor pada alat akan dilakukan perhitungan secara sistematis untuk menentukan berapa nilai koefisien pegasnya. Perhitungan secara sistematis tersebut menggunakan persamaan dasar dapat dituliskan sebagai berikut:

$\mathrm{F}=\mathrm{k} \times \Delta \mathrm{y}$

Dimana:
$\mathrm{F} \quad=$ Gaya yang terjadi pada pegas $(\mathrm{N})$
$\mathrm{K}=$ Konstanta Pegas $(\mathrm{Nm})$
$\Delta \mathrm{y}=$ Perubahan Panjang $(\mathrm{m})$

\section{Hasil dan Pembahasan}

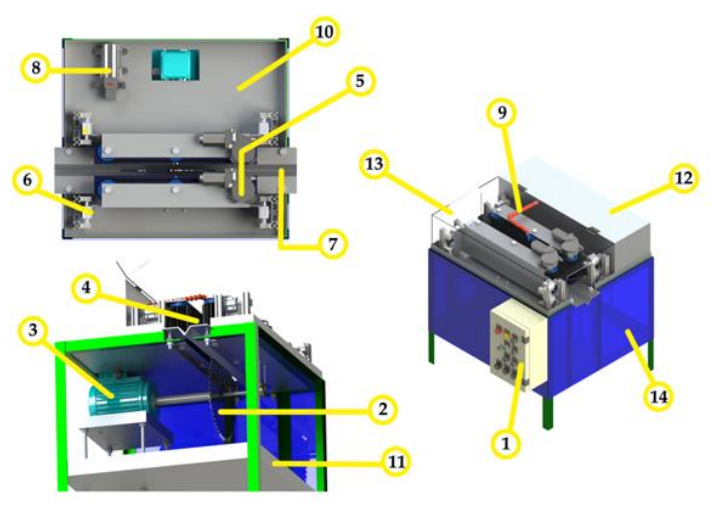

Gambar 7 Realisasi alat

Keterangan

1. Panel box kontrol

8. Water pump DC 12 volt

2. Mata pisau pemotong

3. Motor 1 phase

4. Belt konveyor

penggerak ikan

5. Motor power window

6. Sistem pegas belt

konveyor

7. Plat V untuk peletakkan ikan
Setelah melewati proses studi literatur, perancangan dan realisasi maka berikut ini adalah hasil implementasi alat pada penelitian ini seperti pada gambar 7 .

Dari pengujian yang telah dilakukan pada alat feeder dan pemotongpada mesin pemotong ikan patin otomatis ni, dapat dianalisa hal penting dari setiap data yang diperoleh. Data-data hasil pengujian dapat dilihat pada tabel-tabel berikut ini:

Dilihat dari Tabel 1, data yang diambil adalah hasil pengamatan dari pengujian berat ikan patin terhadap tingkat keberhasilan konveyor mengantarkan ikan patin menuju proses pemotongan menggunakan mata pisau bergerigi berdiameter 10 inch. Pengambilan data tingkat keberhasilan konveyor mengantarkan ikan patin menuju proses pemotongan ini dilakukan sebanyak 20 kali dengan berat ikan bervariasi dari 152 gram sampai dengan 603 gram. Dan dari 20 kali pengujian didapatkan hasil bahwa belt konveyor mampu mengapit ikan patin dan berhasil mengantarkan ikan patin menuju proses pemotongan dengan baik. Selain pengujian tingkat keberhasilan belt konveyor mengantarkan ikan patin menuju proses pemotongan, pengujian selanjutnya adalah pengujian tingkat fleksibilitas konveyor. Dimana pengujian ini bertujuan untuk melihat tingkat fleksibilitas dari sistem pegas yang ada pada sistem konveyor dan juga menentukan berapa nilai konstanta pegasnya, yang mana sistem ini bertujuan untuk menyesuaikan dengan ukuran lebar ikan patin yang digunakan.

Tabel 1 Pengujian keberhasilan konveyor terhadap berat ikan

\begin{tabular}{|c|c|c|c|}
\hline \multirow[t]{2}{*}{$\begin{array}{c}\text { Pengujian } \\
\mathrm{Ke}-\end{array}$} & \multirow[t]{2}{*}{$\begin{array}{l}\text { Berat } \\
\text { (gram) }\end{array}$} & \multicolumn{2}{|c|}{$\begin{array}{l}\text { Keberhasilan Belt Konveyor } \\
\text { Mengapit dan Mengantar Ikan } \\
\text { Menuju Proses Pemotongan }\end{array}$} \\
\hline & & Berhasil & Tidak \\
\hline 1 & 152 & $\checkmark$ & \\
\hline 2 & 190 & $\checkmark$ & \\
\hline 3 & 220 & $\checkmark$ & \\
\hline 4 & 241 & $\checkmark$ & \\
\hline 5 & 245 & $\checkmark$ & \\
\hline 6 & 256 & $\checkmark$ & \\
\hline 7 & 265 & $\checkmark$ & \\
\hline 8 & 279 & $\checkmark$ & \\
\hline 9 & 282 & $\checkmark$ & \\
\hline 10 & 286 & $\checkmark$ & \\
\hline 11 & 287 & $\checkmark$ & \\
\hline 12 & 296 & $\checkmark$ & \\
\hline 13 & 302 & $\checkmark$ & \\
\hline 14 & 304 & $\checkmark$ & \\
\hline 15 & 326 & $\checkmark$ & \\
\hline 16 & 344 & $\checkmark$ & \\
\hline 17 & 350 & $\checkmark$ & \\
\hline 18 & 365 & $\checkmark$ & \\
\hline 19 & 545 & $\checkmark$ & \\
\hline 20 & 603 & $\sqrt{ }$ & \\
\hline
\end{tabular}

Pada Tabel 2 berikut ini, dapat dilihat bahwa setelah dilakukannya pengujian dengan 14 ekor ikan patin 
dengan berat bervariasi, tingkat fleksibilitas konveyor sudah berhasil. Terlihat pada data pengujian ke-13 dan pengujian ke-14 digunakan ikan patin dengan berat sebesar 545 gram dan 603 gram dengan lebar masingmasing sekitar $5 \mathrm{~cm}$ dan $5,9 \mathrm{~cm}$, penggunakaan ikan patin tersebut bertujuan untuk melihat apakah sistem pegas pada sistem konveyor sudah bisa menyesuaikan atau tidak dengan bentuk ikan patin yang lebih besar dan hasil pengamatan dari pengujian tersebut menunjukkan bahwa sistem pegas pada sistem konveyor sudah fleksibel atau dapat menyesuaikan bentuk ikan yang digunakan.

Tabel 2 Pengujian fleksibilitas konveyor

\begin{tabular}{cccc}
\hline $\begin{array}{c}\text { Pengujian } \\
\text { Ke- }\end{array}$ & $\begin{array}{c}\text { Berat } \\
\text { (gram) }\end{array}$ & $\begin{array}{c}\text { Waktu } \\
\text { (sekon) }\end{array}$ & $\begin{array}{c}\text { Keberhasilan } \\
\text { Fleksibilitas } \\
\text { Konveyor } \\
\text { Menyesuaikan } \\
\text { Ukuran Ikan } \\
\text { Patin Yang } \\
\text { Digunakan }\end{array}$ \\
\hline 1 & 265 & 1,66 & $\checkmark$ \\
\hline 2 & 279 & 1,69 & $\checkmark$ \\
\hline 3 & 282 & 1,79 & $\checkmark$ \\
\hline 4 & 286 & 1,80 & $\checkmark$ \\
\hline 5 & 287 & 1,80 & $\checkmark$ \\
\hline 6 & 296 & 1,90 & $\checkmark$ \\
\hline 7 & 302 & 1,98 & $\checkmark$ \\
\hline 8 & 304 & 2,10 & $\checkmark$ \\
\hline 9 & 326 & 2,22 & $\checkmark$ \\
\hline 10 & 344 & 2,35 & $\checkmark$ \\
\hline 11 & 350 & 2,59 & $\checkmark$ \\
\hline 12 & 365 & 3,12 & $\checkmark$ \\
\hline 13 & 545 & 4,30 & \\
\hline 14 & 603 & 7,00 & $\checkmark$ \\
\hline
\end{tabular}

Keterangan:

$\checkmark=$ Berhasil

$X=$ Tidak Berhasil

Setelah melakukan pengamatan terhadap pengujian tingkat fleksibilitas secara langsung, maka dapat dihitung secara matematis berapa nilai konstanta pegas yang digunakan pada konveyor tersebut dengan menggunakan persamaan (1). Untuk perhitungan ini diambil sampel data pengujian ke-1 dan ke-14 yaitu dengan berat ikan sebesar 265 gram dengan lebar ikan sebesar $3 \mathrm{~cm}$ dan berat ikan pada pengujian ke-14 sebesar 603 gram dengan lebar ikan sebesar 5,9 cm, maka dapat dihitung berapakah nilai konstanta pegasnya, dan berikut ini adalah perhitungan secara sistematis untuk menentukan nilai konstanta pegas pada konveyor.

Diketahui:

massa ikan pengujian $\mathrm{ke}-1=0,265 \mathrm{~kg}$

massa ikan pengujian ke-14 $=0,603 \mathrm{~kg}$

Panjang awal pegas $=0,3 \mathrm{~m}$

pengujian ke-1 $=0,27 \mathrm{~m}$

pengujian ke-14 $=0,15 \mathrm{~m}$

Gravitasi $=9,81 \mathrm{~m} / \mathrm{s}$
Terlebih dahulu mencari berapa nilai gaya yang terjadi pada pegas yang digunakan, perhitungannya adalah sebagai berikut:

1. Gaya yang terjadi pada pegas pengujian ke-1

$$
\begin{aligned}
& \mathrm{F}_{\text {ikan pengujian ke-1 }}=\mathrm{m} \times \mathrm{g} \\
& \mathrm{F}_{\text {ikan pengujian ke-1 }}=0,265 \mathrm{~kg} \times 9,81 \mathrm{~m} / \mathrm{s} \\
& \mathrm{F}_{\text {ikan pengujian ke-1 }}=2,59 \mathrm{~N}
\end{aligned}
$$

2. Gaya yang terjadi pada pegas pengujian ke-14

$$
\begin{aligned}
& \mathrm{F}_{\text {ikan pengujian ke-14 }}=\mathrm{m} \times \mathrm{g} \\
& \mathrm{F}_{\text {ikan pengujian ke-14 }}=0,603 \mathrm{~kg} \times 9,81 \mathrm{~m} / \mathrm{s} \\
& \mathrm{F}_{\text {ikan pengujian ke-14 }}=5,91 \mathrm{~N}
\end{aligned}
$$

Setelah didapat berapa nilai gaya yang bekerja pada pegas dimasing-masing pengujian, maka dapat dihitung berapa nilai konstanta pegas dari masingmasing pengujian, yaitu pengujian ke-1 dan pengujian ke-14 seperti berikut ini:

1. Nilai Konstanta Pegas pada Pengujian ke-1

$\mathrm{F}=\mathrm{k} \times \Delta \mathrm{y}$

$\mathrm{k}=\mathrm{F} / \Delta \mathrm{y}$

$\mathrm{k}=2,59 \mathrm{~N} /(0,30 \mathrm{~m}-0,03 \mathrm{~m})=2,59 \mathrm{~N} / 0,27 \mathrm{~m}$

$\mathrm{k}=9,59 \mathrm{~N} / \mathrm{m}$

2. Nilai Konstanta Pegas pada Pengujian ke-14

$\mathrm{F}=\mathrm{k} \times \Delta \mathrm{y}$

$\mathrm{k}=\mathrm{F} / \Delta \mathrm{y}$

$\mathrm{k}=5,91 \mathrm{~N} /(0,30 \mathrm{~m}-0,15 \mathrm{~m})=5,91 \mathrm{~N} / 0,15 \mathrm{~m}$

$\mathrm{k}=63,4 \mathrm{~N} / \mathrm{m}$

Setelah dilakukan perhitungan nilai konstanta pegas pada masing-masing pengujian, yaitu pada pengujian ke-1 dan pengujian ke-14, nilai konstanta pegas yang didapat dari perhitungan secara sistematis tersebut adalah sebesar 9,59 Nm untuk pengujian ke-1 dengan berat ikan sebesar 265 gram dan lebar ikan sebesar $3 \mathrm{~cm}$ dan untuk pengujian ke-14 nilai konstanta pegas yang didapat adalah sebesar $63,4 \mathrm{Nm}$ dengan berat ikan sebesar 603 gram dan lebar ikan sebesar 5,9 cm. Berikutnya adalah pengujian terhadap tingkat keberhasilan proses pemotongan ikan patin, data hasil pengujian dapat dilihat pada Tabel 3 berikut ini:

Tabel 3 Pengujian keberhasilan proses pemotongan

\begin{tabular}{c|c|c}
\hline No. & $\begin{array}{c}\text { Berat Ikan Patin } \\
\text { (gram) }\end{array}$ & $\begin{array}{c}\text { Keberhasilan Pengujian Proses } \\
\text { Pemotongan Ikan }\end{array}$ \\
\hline 1 & 152 & $\checkmark$ \\
\hline 2 & 190 & $\checkmark$ \\
\hline 3 & 220 & $\checkmark$ \\
\hline 4 & 241 & $\checkmark$ \\
\hline 5 & 245 & $\checkmark$ \\
\hline 6 & 256 & $\checkmark$ \\
\hline 7 & 265 & $\checkmark$ \\
\hline 8 & 279 & $\checkmark$ \\
\hline 9 & 282 & $\checkmark$ \\
\hline 10 & 286 & $\checkmark$ \\
\hline 11 & 287 & $\checkmark$ \\
\hline 12 & 296 & $\boldsymbol{x}$ \\
\hline 13 & 302 & $\boldsymbol{x}$ \\
\hline 14 & 304 & $\checkmark$ \\
\hline 15 & 326 & $\checkmark$ \\
\hline 16 & 344 & \\
\hline
\end{tabular}




\begin{tabular}{c|c|c}
\hline 17 & 350 & $\checkmark$ \\
\hline 18 & 365 & $\mathbf{x}$ \\
\hline 19 & 545 & $\mathbf{x}$ \\
\hline 20 & 603 & $\mathbf{x}$ \\
\hline
\end{tabular}

Keterangan:

$\checkmark=$ Berhasil Terpotong

$\mathbf{X}=$ Tidak Berhasil Terpotong

Dari Tabel 3 diatas, dapat dilihat bahwa proses pemotongan ikan patin dengan berat standar yang dipakai dipasaran yang berkisar dari 150 sampai 250 gram dalam pengujian ini ikan yang dipakai yaitu dari berat 152 gram sampai 296 gram ikan berhasil terpotong. Sedangkan untuk ukuran berat 302 gram, 304 gram, tidak terbasil terpotong karena pada saat pengujian menggunakan mata pisau berdiameter 7 inch dengan kendala ikan terlalu jauh dari mata pisau saat proses pemotongan dan juga ikan yang mengalami stagnasi karena peletakkan ikan terlalu rendah sehingga mata pisau tidak terbebas dari punggung ikan yang keras. Sedangkan dengan berat 365 gram, 545 gram dan 603 gram ikan tidak berhasil terpotong meski

sudah dilakukan pergantian mata pisau menjadi mata pisau berdiameter 10 inch, ini dikarenakan ukuran ikan yang digunakan terlalu besar sehingga mata pisau masih tidak terbebas dan mengalami stagnasi yang juga diakibatkan oleh sirip ikan yang berada pada sisi kanan dan kiri ikan yang cukup keras tersangkut pada sela-sela antara plat $\mathrm{v}$ dengan pulley belt konveyor. Proses pemotongan ikan patin dapat dilihat pada Gambar 3.1 berikut ini.
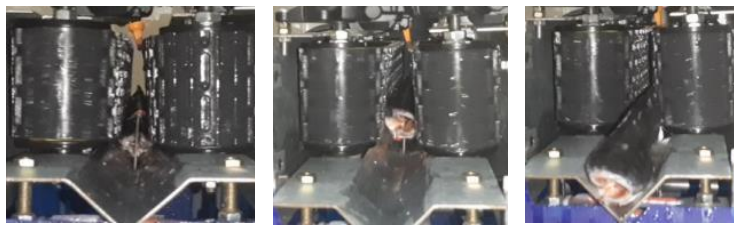

Gambar 6: Proses pemotongan ikan

Dari Tabel 3 dapat dilihat bahwa proses pemotongan ikan patin dengan berat standar yang dipakai dipasaran yang berkisar dari 150 sampai 250 gram dalam pengujian ini ikan patin yang dipakai yaitu dari berat 152 gram sampai 296 gram ikan berhasil terpotong dengan baik. Salah satu indikator keberhasil tersebut dapat dilihat dari bentuk fisik ikan setelah pemotongan, apabila ikan yang sudah Set melewati proses pemotongan akan tetapi tengkorak kepala mata pisau berdiameter 10 inch dengan jumah teeth ikan patin hancur, maka proses pemotongan dikatakan sebanyak 120 teeth hasil pemotongan sudah gagal atau hasil pemotongannya tidak sempurna. Gambar dikatakan berhasil, dan hasil pemotongan dapat dilihat 7 berikut merupakan gambaran hasil pemotongan ikan pada Gambar 3.3, dan terlihat bahwa hasil patin yang gagal.
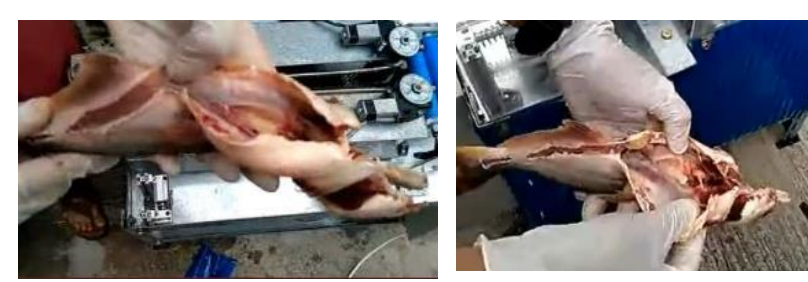

Gambar 7: Hasil pemotongan ikan yang gagal
Selain itu, dari Tabel 3 tersebut juga dapat dilihat juga bahwa untuk ikan patin dengan berat 302 gram dan 304 gram, dinyatakan tidak berhasil dalam proses pemotongannya. Hal ini dikarenakan pada saat pengujian menggunakan 2 ekor ikan tersebut, diameter mata pisau yang digunakan masih berukuran 7 inch. Kendala yang dialami pada saat menggunakan mata pisau berdiameter 7 inch tersebut dengan berat 302 gram ikan tidak terpotong dengan baik, karena proses peletakkan ikan patin terlalu tinggi dari mata pisau dan mata pisau sudah tidak bisa diatur lagi ketinggiannya dikarenakan bentuk motor yang digunakan sudah terantuk dengan meja yang digunakan. Sedangkan untuk berat 304 gram ikan patin diletakkan terlalu rendah sehingga ikan mengalami stagnasi pada proses pemotongan, stagnasi tersebut diakibatkan karena mata pisau tidak terbebas dari punggung ikan yang cukup keras, selain itu juga kendala lainnya adalah dikarenakan sirip ikan yang berada disisi kanan dan kiri ikan yang tersangkut pada sela-sela pulley belt dan plat V.

Sedangkan, untuk hasil pemotongan yang dikatakan berhasil atau terpotong sempurna adalah jika ikan terbelah menjadi dua dan tidak terpotong habis sampai ke bagian ekor. Setelah dilakukan redesain dengan menggunakan mata pisau berdiameter 10 inch dengan jumlah teeth sebanyak 120 teeth, hasil pemotongan sudah dikatakan berhasil, dan hasil pemotongan dapat dilihat pada Gambar 8 .
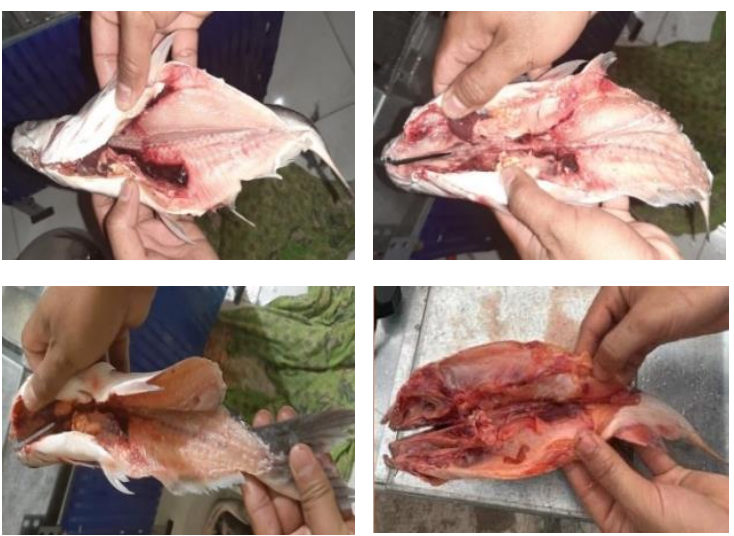

Gambar 8: Hasil pemotongan ikan patin yang berhasil terpotong atau terpotong dengan baik pemotongan ikan sudah dapat membelah ikan dengan kedalaman yang sesuai dan tidak terpotong habis sampai ke bagian ekor. Dan dari Tabel 3 juga dapat dilihat bahwa proses pemotongan ikan patin dengan berat standar yang dipakai dipasaran yang berkisar dari 150 sampai 250 gram dalam pengujian ini ikan patin yang dipakai yaitu dari berat 152 gram sampai 296 gram ikan berhasil terpotong. Sedangkan untuk ikan patin dengan berat 365 gram, 545 gram dan

102 | Jurnal Integrasi | Vol.13 No.2, October 2021, 97-105 | e-ISSN: 2548-9828 
603 gram ikan tidak berhasil terpotong dengan baik atau bisa dikatakan gagal dalam proses pemotongan meski mata pisau telah diganti dengan diameter yang lebih besar yaitu 10 inch.

Ada beberapa faktor yang mempengaruhi gagalnya proses pemotongan pada alat feeder dan pemotong pada mesin pemotong ikan patin untuk proses pembuatan ikan salai ini, diantaranya adalah Peletakkan ikan yang terlalu tinggi dan jauh dari mata pisau, ketidaksesuaian ini juga bisa diakibatkan oleh perkiraan jarak yang salah pada saat proses pengumpanan ikan patin. Selain itu, faktor yang mempengaruhi gagalnya proses pemotongan ikan patin ini yaitu ikan patin tersendat pada proses pemotongan karena mata pisau tidak terbebas dari punggung ikan yang cukup keras, tersendatnya ikan juga diakibatkan oleh sirip yang berada pada sisi kanan dan kiri ikan yang cukup keras tersebut tersangkut pada sela-sela pulley belt dan plat V. Selanjutnya adalah data pengujian durasi keseluruhan proses untuk 20 ekor ikan patin dengan berat yang bervariasi yang dapat dilihat pada Tabel 4, sedangkan untuk data pengujian durasi keseluruhan proses untuk ikan patin berukuran 150-250 gram dapat dilihat pada Tabel 5. Proses pengambilan data dilakukan dengan menggunakan stopwatch. Pada Tabel 4, dapat dilihat bahwa Data yang diambil adalah durasi yang dibutuhkan untuk melakukan keseluruhan sistem yaitu, dari proses feeder (pengumpanan) ikan sampai dengan ikan patin terpotong. Dalam proses pengambilan data juga ditetapkan variabel bebas yaitu jenis ikan patin yangdigunakan berkisar 152 gram sampai dengan 603 gram.

Tabel 4 Pengujian waktu proses pada berat ikan bervariasi

\begin{tabular}{|c|c|c|c|}
\hline \multirow{2}{*}{$\begin{array}{l}\text { Pengujian } \\
\text { ke- }\end{array}$} & \multicolumn{3}{|c|}{$\begin{array}{c}\text { Keseluruhan Proses Alat } \\
\text { (Proses feeder sampai selesai pemotongan) }\end{array}$} \\
\hline & $\begin{array}{l}\text { Berat } \\
(\text { gram })\end{array}$ & Panjang $(\mathrm{cm})$ & Waktu (sekon) \\
\hline 1 & 152 & 23 & 1,26 \\
\hline 2 & 190 & 23 & 1,40 \\
\hline 3 & 220 & 28 & 1,52 \\
\hline 4 & 241 & 28 & 1,62 \\
\hline 5 & 245 & 27 & 1,62 \\
\hline 6 & 256 & 28 & 1,66 \\
\hline 7 & 265 & 32 & 1,66 \\
\hline 8 & 279 & 29 & 1,69 \\
\hline 9 & 282 & 32 & 1,79 \\
\hline 10 & 286 & 33 & 1,80 \\
\hline 11 & 287 & 33 & 1,80 \\
\hline 12 & 296 & 33 & 1,90 \\
\hline 13 & 302 & 33 & 1,98 \\
\hline 14 & 304 & 33 & 2,10 \\
\hline 15 & 326 & 32 & 2,22 \\
\hline 16 & 344 & 33 & 2,35 \\
\hline 17 & 350 & 33 & 2,59 \\
\hline 18 & 365 & 35 & 3,12 \\
\hline 19 & 545 & 39 & 4,30 \\
\hline 20 & 603 & 39 & 7,00 \\
\hline
\end{tabular}

Dilihat dari Tabel 4, data yang diambil adalah durasi yang dibutuhkan untuk memproses ikan patin dari awal proses feeding (Pengumpanan) ikan patin dengan berat bervariasi yaitu 1,26 sekon untuk ikan patin dengan berat sebesar 152 gram dan data durasi tertinggi untuk keselurhan proses ini yaitu 7,00 sekon untuk ikan patin dengan berat sebesar 603 gram. sampai akhir pemotongan ikan. Pengambilan data ini dilakukan dengan menggunakan stopwatch. Dari pengujian tersebut didapatkan data durasi terendah dari keseluruhan proses untuk mengolah 20 ekor ikan patin dengan berat bervariasi yaitu 1,26 sekon untuk ikan patin dengan berat sebesar 152 gram dan data durasi tertinggi untuk keselurhan proses ini yaitu 7,00 sekon untuk ikan patin dengan berat sebesar 603 gram. Dari data pengujian yang terdapat pada Tabel 4, maka dapat dihitung secara matematis berapa durasi rata-rata yang dibutuhkan alat untuk memproses 20 ekor ikan patin dengan berat bervariasi tersebut.

Waktu Rata-rata $=$ wpk $1+$ wpk2 $+\ldots+$ wpk20 $/ 20$

$=(1,26+1,40+\ldots .+7,00) / 20$

$=45,38 \mathrm{~s} / 20$

$=2,27 \mathrm{~s}$

Ket : wpk $=$ waktu pengujian ke-

Setelah dilakukannya riset ulang mengenai berapa berat ikan patin yang digunakan sebagai bahan baku olahan ikan salai patin dan didapat berat ideal yang digunakan adalah sebesar 150 gram sampai degan 250 gram. Maka dilakukan pengujian untuk ikan patin dengan ukuran berkisar dari 150-250 gram yang datanya dapat dilihat pada Tabel 5 berikut ini.

Tabel 5 Pengujian waktu proses pada berat ikan ideal untuk bahan baku ikan salai

\begin{tabular}{cccc}
\hline \multirow{2}{*}{$\begin{array}{c}\text { Pengujian } \\
\text { ke- }\end{array}$} & \multicolumn{3}{c}{$\begin{array}{c}\text { Keseluruhan Proses Alat } \\
\text { (Proses feeder } \text { sampai selesai pemotongan) }\end{array}$} \\
\cline { 2 - 4 } & $\begin{array}{c}\text { Berat } \\
\text { (gram) }\end{array}$ & Panjang (cm) & Waktu (sekon) \\
\hline 1 & 152 & 23 & 1,26 \\
\hline 2 & 190 & 23 & 1,40 \\
\hline 3 & 220 & 28 & 1,52 \\
\hline 4 & 241 & 28 & 1,62 \\
\hline 5 & 245 & 27 & 1,62 \\
\hline 6 & 256 & 28 & 1,66 \\
\hline
\end{tabular}

Dari data pengujian yang terdapat pada Tabel 5, maka dapat dihitung durasi rata-rata dari keseluruhan proses untuk mengolah ikan dengan berat 152 gram sampai dengan 256 gram yang terdapat pada pengujian ke-1 sampai pengujian ke-6 dari Tabel 5. Berikut perhitungan secara sistematis untuk keseluruhan proses.

Waktu rata-rata $=w p k 1+w p k 2+\ldots+w p k 6 / 6$

$=(1,26+1,40+1,52+1,62+1,66) / 6$

$=9,08 \mathrm{~s} / 6=1,51 \mathrm{~s}$

Dari perhitungan durasi rata-rata diatas didapatkan 
hasil bahwasannya durasi rata-rata alat untuk memproses ikan patin dengan ukuran berkisar 152 gram sampai dengan 256 gram yang sesuai dengan berat ideal yang ada dipasaran sebesar 1,51 sekon.

Dan dari Tabel 4 dapat dilihat bahwasannya ikan patin dengan berat 545 gram dan 603 gram, durasi yang didapat dari keseluruhan proses adalah 4,30 sekon dan 7,00 sekon. Hal ini dikarenakan pada saat dilakukannya proses pengujian terdapat kendala yang menghambat dalam proses pemotongan, yaitu ikan tersendat cukup lama pada proses pemotongan dikarenakan ikan patin terlalu kebawah pada saat peletakkan secara manual sehingga terhambat oleh sirip yang terdapat dikanan dan kiri badan ikan. Selain itu, kerasnya bagian punggung ikan juga menyebabkan mata pisau sulit untuk memotong ikan patin tersebut.

Selain pengujian durasi keseluruhan proses, tingkat keberhasilan konveyor dan tingkat keberhasilan proses pemotongan, dilakukan juga pengujian alat untuk menentukan kapasitas ikan patin yang dapat diproses oleh alat feeder dan pemotong pada mesin pemotong ikan patin otomatis ini dengan cara melakukan pengujian secara kontinu dengan 5 ekor ikan. Dan didapatkan durasi sebesar 6,02 sekon per 5 ekor ikan, maka dapat dihitung berapa kapasitas ikan patin yang dapat di proses oleh alat ini dalam rentang waktu satu menit. Berikut ini perhitungan secara sistematis dari penentuan kapasitas ikan patin yang dapat diproses dalam rentang waktu satu menit

Diketahui:

Durasi keseluruhan proses per lima ikan $=6,02$ sekon Durasi keseluruhan proses per satu ikan $=1,24$ sekon Maka kapasitas ikan/menit $=1$ menit $/$ 1,24 sekon

Kapasitas ikan/menit $=60$ sekon $/ 1,24$ sekon

Kapasitas ikan $/$ menit $=48,38$ ekor

Dilihat dari perhitungan diatas bahwasannya dalam waktu satu menit, ikan patin yang dapat diproses oleh alat feeder dan pemotong pada mesin pemotong ikan patin otomatis ini adalah sebanyak 48 sampai dengan 49 ekor ikan/menit.

Selain itu, dilakukan juga perhitungan perkiraan biaya konsumsi daya pada alat feeder dan pemotong pada mesin pemotong ikan patin otomatis untuk proses pembuatan ikan salai ini. Untuk mengetahui perkiraan konsumsi daya dari Alat Feeder Dan Pemotong Pada Mesin Pemotong Ikan Patin Otomatis Untuk Proses Pembuatan Ikan Salai, maka dilakukanlah pengukuran arus menggunakan Tang Ampere (Digital Clamp Multimeter), sehingga dapat dihitung biaya yang harus dikeluarkan untuk menyuplai daya Alat Feeder Dan Pemotong Pada Mesin Pemotong Ikan Patin Otomatis Untuk Proses Pembuatan Ikan Salai ini. Pengukuran arus secara langsung menggunakan Tang Meter adalah 0,89 A. Pengukuran ini dilakukan diawal kabel supply semua rangkaian Alat Feeder Dan Pemotong Pada Mesin Pemotong Ikan Patin Otomatis
Untuk Proses Pembuatan Ikan Salai, sehingga arus yang terukur adalah arus total rangkaian. Tegangannya adalah AC, yaitu $220 \mathrm{~V}$, sehingga untuk mendapatkan daya, arus dikali tegangan, Maka secara matematis dapat dihitung sebagai berikut:

$$
\begin{aligned}
& P=\mathrm{V} \times I \\
& P=220 v \times 0,89 \mathrm{~A} \\
& P=195,8 \mathrm{Watt} \\
& P=0,1958 \mathrm{KWatt}
\end{aligned}
$$

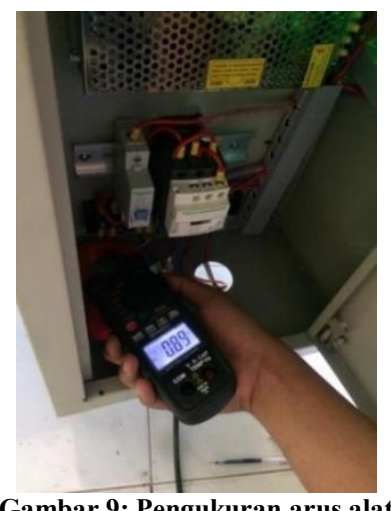

Sehingga berdasarkan data ini dan tarif listrik 1300 Watt PLN sebesar Rp 1.444,7 /KWh dapat dihitung biaya pengoperasian alat ini per jam adalah sebesar $=\mathrm{Rp} 1.444,7 / \mathrm{KWh} \times 0,1958 \mathrm{KW}$ $=282,87 / \mathrm{h}$

Jika dianggap Alat Feeder Dan Pemotong Pada Mesin Pemotong Ikan Patin Otomatis Untuk Proses Pembuatan Ikan Salai ini bekerja 8 jam sehari selama 30 hari maka Rp 282,87/h x 8 jam x 30 hari $=\mathrm{Rp}$ $67.888,8$ /bulan.

\section{Kesimpulan}

Setelah semua proses pada perancangan, pembuatan, dan pengambilan data pada Alat Feeder dan Pemotong pada Mesin Pemotong Ikan Patin Otomatis untuk Proses Pembuatan Ikan Salai, maka dapat disimpulkan bahwa durasi rata-rata pengolahan setiap ikan adalah sebesar 2,27 detik. Dengan menggunakan 5 ekor ikan patin yang diuji secara kontinu, maka didapat kapasitas output ikan patin yang dapat diolah dari alat ini, sebanyak 48-49 ekor ikan per menit. Belt konveyor mampu mengantarkan ikan menuju proses pemotongan dan juga ketahap akhir setelah pemotongan dengan baik dengan variasi berat ikan berkisar pada 152 gram sampai 603 gram per ekor. Faktor yang membuat ikan patin tersedat atau tertahan pada proses pemotongan ini dikarenakan mata pisau yang tidak terbebas dari punggung ikan yang cukup keras, tersendatnya ikan juga diakibatkan oleh sirip yang berada pada sisi kanan dan kiri ikan yang cukup keras tersebut tersangkut pada sela- sela konveyor. Dengan asumsi Alat Feeder Dan Pemotong Pada Mesin Pemotong Ikan Patin Otomatis bekerja 8 jam sehari selama 30 hari maka biaya operasional listrik yang dibutuhkan adalah sebesar $\mathrm{Rp}$ $67.888,8$ /bulan 


\section{Acknowledgment}

Dari hati yang paling dalam penulis mengucapkan banyak terimakasih kepada semua pihak yang sudah terlibat dan membantu dalam penelitian ini terutama kepada BP2M Politeknik Caltex Riau yang sudah mendukung penelitian ini dan semoga penelitian ini bermanfaat dan dapat berkontribusi bagi semua pihak baik akademisi maupun praktisi.

\section{References}

[1] Suryana Dayat, Ternak Ikan Patin: Budidaya Ikan, CreateSpace Independent Publishing Platform, Jakarta, 2013.

[2] Desmelati dan Wisuda S Shanty, Buku Ensiklopedia Pengolahan Dan Industri Ikan Salai Di Provinsi Riau, Deepublish, Jakarta, 2019

[3] Hakim M Lukman. Perancangan Kecepatan Pisau Potong Ikan Sarden Berbasis PID (Proportional Integral Derivative) Controller. Skripsi, Universitas Jember, 2019.

[4] Manual book, Filleting Machine CT 2630, Marel Industries, https://marel.com/en/products/filleting-machinect-2630/fish/salmon: Juni 2021.

[5] Manual book, FGB-168 Small Fish Filleting Machine, FENGXIANG Food Machinery, http://www.fx-

foodmachine.com/sdp/338252/4/pd1495215/13261787-2294721/FGB-

168_fish_slicing_machine.html, Mei 2021. 